\title{
A sustainable electricity blueprint for Brazil
}

\author{
Giulio Volpi \\ WWF Climate and Energy Programme for Latin America and the Caribbean, clo WWF-Brasil \\ SHIS EQ QL 6/8 Conjunto “E”, 71620-430 - Brasilia, DF, Brazil \\ E-mail: giulio@wwf.org.br
}

\begin{abstract}
Gilberto Jannuzzi ${ }^{[1]}$
Universidade Estadual de Campinas-UNICAMP, Faculdade de Engenharia Mecânica,Departamento de Energia CP 6122 Campinas 13083-970 SP, Brazil
\end{abstract}

\author{
Rodolfo Dourado Maia Gomes \\ International Energy Initiative - Latin American Regional Office, Caixa Postal 6163 \\ Campinas - SP, CEP 13083-970, Brazil
}

\begin{abstract}
Brazil, South America's largest country and leading energy consumer, faces the twofold challenge of energy and environmental security. More than $80 \%$ of Brazil's installed generating capacity of about 70,000 MW is hydroelectric, generated by the nation's 450 dams [BEN, 2005], which explains why Brazilian power generation is cleaner with regard to local pollutants and greenhouse gas emissions. On the other hand, such hydropower dependency not only has led to significant negative impacts on Brazil's rivers and river-based communities, but also makes the country vulnerable to energy shortages from droughts, which are projected to increase due to climate change.

Official estimates suggest that under a business-as-usual (BAU) scenario, Brazil's electricity demand will grow by about $5 \%$ a year over the next 15 years, as energy-intensive industries develop and consumer demand increases, meaning that the country will need to more than double its existing capacity by 2020. At the last auction for new power plants, held in December 2005, Brazil started to increase its consumption of fossil fuels. On that occasion, coal-, oil- and natural gas-fired plants were contracted to supply $70 \%$ of the 3,286 megawatts $(M W)$ of the auctioned electric power.

This study presents the view that with more aggressive policies for reducing power waste both at the production and consumption level and promoting new renewable energy, Brazil could cut by $38 \%$ the projected power demand growth by 2020 - equal to a saving of 293 TWh, avoiding 74.6 GW of installed capacity and saving of US\$ 15 billion. In turn, this would create up to 8 million new jobs and stabilise Brazil's carbon dioxide $\left(\mathrm{CO}_{2}\right)$ emissions to 2004 levels by 2020.

The major challenge for policy-makers will be in designing and stimulating an effective market and implementation programmes for energy efficiency and renewable energy technologies in order to accomplish such ambitious results presented in the study. Therefore, the study proposes nine broad public policies that are necessary to meet these targets.
\end{abstract}

\section{Introduction}

Brazil, South America's largest country and leading energy consumer, faces the twofold challenge of energy and environmental security. More than $80 \%$ of Brazil's power generation, corresponding to an installed generating capacity of about $70 \mathrm{GW}$, is hydroelectric [BEN, 2005], which is the key factor behind the low carbon intensity of Brazil's power supply. Meanwhile, such hydropower dependency, distributed through Brazil's 450 dams, not only has led to significant negative impacts on Brazil's rivers and river-based communities, but also makes the power sector vulnerable to droughts, which are projected to worsen due to climate change. For instance, since 2001, southern Brazil has been going through the worst drought in 20, perhaps 50, years. This not only reduced South America's famous Iguaçu Falls to a trickle in March 2006, but also threatened hydropower production in the south of the country [NAE, 2005; Greenpeace, 2006].

The rest of Brazil's installed power capacity mix comes from natural gas $(11 \%)$, oil $(6 \%)$ coal $(2 \%)$ nuclear power $(3 \%)$, and new renewables such as biomass, small hydro and wind power (which combined account for less than $4 \%$ ) [BEN, 2005]. Official estimates suggest that under a business-as-usual scenario (BAU), Brazil's electrical energy demand will grow by about $5 \%$ per year over the next 15 years, as energy-intensive industries develop and consumer demand increases, meaning that the country will need to more than double its existing capacity by 2020 . At the last power auction held in December 2005, Brazil started to increase its consumption of fossil fuels. On that occasion, coal-, oil- and natural gas-fired electric plants were contracted to supply $70 \%$ of the 3,286 megawatts (MW) of the auctioned electric power [MME, 2006]. 


\section{Articles}

Such a trend towards a growing share of fossil fuels within the national power mix could prove risky from both an economic and a security viewpoint, as it increases the country's dependency on foreign imported natural gas. It could also jeopardise the country's international leadership on climate change, particularly in the context of the international negotiations on the second phase of the Kyoto Protocol. For instance, once built, the 2005 auctioned power plants will emit about 11 millions tonnes (Mt) of $\mathrm{CO}_{2}$ per year - which represent a $11 \%$ growth compared to the current energy-related emissions. This is more than four times the emissions that a large-scale national programme called PROINFA plans to save, aiming to install 3,300 MW of electricity generation capacity from non-traditional renewable energy resources such as wind, sustainable biomass and small hydro.

The electric energy choices Brazil makes over the next 15 years are critical for its energy security, economic development and global and local environmental protection. With this background, WWF (the Worldwide Fund for Nature) Brazil commissioned the University of Campinas and the International Energy Initiative to investigate a scenario - called PowerSwitch (PSW) - for meeting Brazil's electric energy needs by 2020 in a sustainable way. The PSW scenario aims to minimise economic costs and socio-environmental impacts, while strengthening the country's economic competitiveness and promoting job creation. To contrast what is likely to happen in the absence of new low-carbon energy policy initiatives, the study also developed a BAU scenario.

With more aggressive policies for reducing power waste at both the production and the consumption level and promoting new renewable energy sources, Brazil could cut by $38 \%$ the projected power generation growth by 2020 - equal to a saving of $293 \mathrm{TWh}$, avoidance of 74.6 GW of installed capacity and a saving of US\$ 15 billion. In turn, this would create up to 8 million new jobs and stabilise Brazil's carbon dioxide $\left(\mathrm{CO}_{2}\right)$ emissions that contribute to global warming to 2004 levels by 2020 .

This paper summarises the full study (which is available in Portuguese at www.wwf.org.br). It describes the methodology used (Section 2), presents the BAU and PSW scenarios (Section 3), identifies the key energy efficiency and renewable energy options (Section 4), compares the two different scenarios (Section 5), discusses the costs of market transformation (Section 6), draws a number of conclusions (Section 7), and identifies the policies for realising the PSW scenario (Section 8).

\section{Methodology}

The methodology used for this study is based on the principles of the integrated resource planning (IRP) ${ }^{[2]}$, and adopts a "bottom-up" approach which essentially looks at the opportunities to reduce power demand by improving energy efficiency on both the supply and demand sides. It then investigates the feasibility of meeting the projected electricity demand through the maximum share of nonconventional renewable energy, such as biomass, wind power, and small hydropower. It builds upon extensive

\section{Box 1. Key clean energy options analyzed}

\section{Supply-side reductions}

- Efficiency increases of existing power plants (both hydropower and thermal)

- Increase in the amount of distributed generation, particularly sugar-bagasse combined heat and electricity production

- Reduction of losses in the electricity transmission and distribution system

- Increased use of wind, small hydropower and biomass for electricity production

\section{Demand-side options}

- Introduction of energy-efficient motors in industry

- Best-practice appliances and cooling equipment in the household sector

- Replacement of electric water heaters with solar water heaters

- Energy-efficient office equipment, lighting and cooling

- Appliances with low stand-by losses $(<1 \mathrm{~W})$ in the household sector.

data broken down into end-use sectors such as households, industry and services. Box 1 summarizes the main options assessed.

A host of studies have also shown that the technical potential for energy efficiency improvements on the supply and demand sides and the potential for developing renewable energy is very large [Jannuzzi, 2004; World Bank, 2006]. We live in an imperfect world, however, and not all of the technical or economic options for energy conservation will necessarily be adopted ${ }^{[3]}$. Hence the study makes a number of assumptions to produce what is termed a "realistic" technical potential. While this is a subjective term, in this study it was assumed that:

- power plants, appliances and other technologies would not be replaced before the end of their economic lifetime;

- the rate of introduction of more energy-efficient appliances was based on "real-life" past experiences in progressive countries where a strong policy effort to stimulate the market for these appliances was made; and

- the rate of introduction of renewable energy sources was based again mainly on "real-life" experience in countries where progressive policies to stimulate the renewable energy market were used.

Overall, the assumptions of the study are challenging, but credible and realistic mainly by assuming the widespread adoption of rates of energy efficiency and renewable energy already achieved in the past and in a number of other countries.

\section{Building energy scenarios}

The study presents two alternative scenarios of electricity 


\section{Articles}

Table 1. Total power demand in 2004 and BAU projections for 2020 (TWh)

\begin{tabular}{|c|c|c|c|}
\hline \multirow[b]{2}{*}{ Sectors/ consumption } & \multirow{2}{*}{$\begin{array}{c}\begin{array}{c}\text { Current } \\
\text { year }\end{array} \\
2004 \\
\text { (TWh) }\end{array}$} & \multicolumn{2}{|r|}{ BAU } \\
\hline & & $\begin{array}{c}2020 \\
\text { (TWh) }\end{array}$ & $\begin{array}{c}\text { Annual } \\
\text { growth rate (\%) } \\
(2004-2020)\end{array}$ \\
\hline Residential & 78.6 & 172.3 & 5.0 \\
\hline $\begin{array}{l}\text { Commercial and } \\
\text { public services }\end{array}$ & 80.2 & 176.4 & 5.1 \\
\hline Industrial & 172.1 & 354.0 & 4.6 \\
\hline Total power consumption & 330.8 & 702.7 & 4.8 \\
\hline Required power generation $^{[1]}$ & 383.7 & 794.1 & 4.6 \\
\hline
\end{tabular}

Note

1. Includes transmission and distribution losses of $13 \%$ by 2020; in 2004, losses were estimated at $16 \%$. Losses include technical and commercial losses in 2004, but it is assumed that all commercial losses will be phased out by 2020 .

Table 2. Installed capacity and fuel mix in 2004 and 2020 under the BAU and PSW scenarios (GW)

\begin{tabular}{|l|r|c|c|}
\hline & $\mathbf{2 0 0 4}$ & BAU 2020 & PSW 2020 \\
\hline Hydropower & 69.2 & 122.0 & 74.7 \\
\hline Natural gas & 10.1 & 30.2 & 9.5 \\
\hline Petroleum & 5.2 & 11.8 & 5.0 \\
\hline Coal & 1.4 & 6.0 & 1.9 \\
\hline Nuclear & 2.0 & 3.6 & 1.9 \\
\hline Biomass & 3.1 & 7.6 & 9.0 \\
\hline Wind power & 0.0 & 6.5 & 8.2 \\
\hline Small hydro & 1.2 & 5.4 & 6.9 \\
\hline Photovoltaic & - & - & 1.6 \\
\hline Total & 92.1 & 193.2 & 118.6 \\
\hline
\end{tabular}

demand by 2020 . To contrast what is likely to happen in the absence of new policy initiatives, the study first developed a BAU scenario. This utilized results from official estimates [MME, 2006; Petrobras, 2005; MME, 2002]. These studies suggest that under a BAU scenario, Brazil's power demand will grow by $4.8 \%$ a year over the next 15 years. In the absence of aggressive policies to overcome the wider adoption of efficient energy-use technologies, many opportunities go unrealized and power consumption increases from $330.8 \mathrm{TWh}$ in 2004 up to 702.7 TWh in 2020 (see Table 1). This will require a total installed capacity of $193 \mathrm{GW}$, up from the current $92 \mathrm{GW}$ (Table 2).

These estimates are based on a continuation of the current patterns of energy use in Brazil, where energy-intensive industries, principally companies that process aluminium, metal alloys and cement, consumed more than $50 \%$ of the total electricity production in 2004 . The remaining power demand is roughly equally divided between the commercial and public service sectors and the residential sector, accounting respectively for $80.2 \mathrm{TWh}$ and 78.6 TWh. From this BAU scenario, realistic electricity reduction potentials were then assessed for the year 2020, the so-called "Power Switch" scenario.

\section{Key energy efficiency and renewables options}

The PSW scenario (see Figure 1) includes the following measures to increase energy efficiency on both the supply and demand sides (see Figure 2) and meet projected electricity demand with new and sustainable renewable energy sources (see Figure 3).

\subsection{Supply-side options}

- Retrofitting power plants. It was assumed that retrofitting larger hydro plants could improve the supply by $10 \mathrm{GW}$ - roughly equal to the capacity of one Itaipu hydropower plant - even though studies indicate a potential of up to $32 \mathrm{GW}$ for a cost of Brazilian reals (R\$) 250-600 per additional $\mathrm{kW}(\mathrm{R} \$ 2.13=\mathrm{US} \$ 1)$.

- More efficient new thermal electric power plants. New combined-cycle natural gas $(\mathrm{CCNG})$ plant could reach efficiencies of $60-65 \%$, compared to the current $35 \%$ efficiency rates of open-cycle power plants. The PSW scenario assumes an average efficiency of $45 \%$ by 2020 .

- Reduction of power losses. It is estimated that about $16 \%$ of the generated power is lost through the transmission and distribution system, compared with an international standard of about $6 \%$. Through the introduction of more efficient power tranformers, the PSW scenario assumes the reduction of losses to $7 \%$ by 2020 - equal to the average loss rate of the United States in 2004.

- Network management. Efficiency gains achieved through new dispatch criteria for hydropower output, in coordination with thermal electric power production, and better power line management are assumed to result in a $1 \%$ power generation increase.

- Cogeneration and distributed generation. Significant energy savings can be obtained through distributed generation, such as by natural gas-fired micro-turbines, and cogeneration - the combined production of heat and electricity. It was assumed that these energy systems would supply $4 \%$ of the 2020 generation, even though studies indicate a $10-15 \%$ potential.

- Bioenergy. Although a range of technologies including gasification and anaerobic digestion could be used in Brazil, bagasse cogeneration is currently the most attractive option. Bioenergy production is complementary to hydropower in the southern and south-eastern regions, as the biomass feedstock harvest, such as sugar cane and rice waste, takes place during the dry season. With an assumed $20 \%$ cost reduction by 2020 , installed capacity will increase by about $6 \mathrm{GW}$.

- Wind power. The PSW scenario assumes wind power will supply $6 \%$ of the total electrical generation capacity by 2020 , requiring an installed capacity of 8.2 $\mathrm{GW}$,.compared to a technical potential estimated at 143 GW - double the country's current installed hydropower capacity. That is only $11 \%$ of the technical power generation potential (273 TWh/year). A $15 \%$ 


\section{Articles}

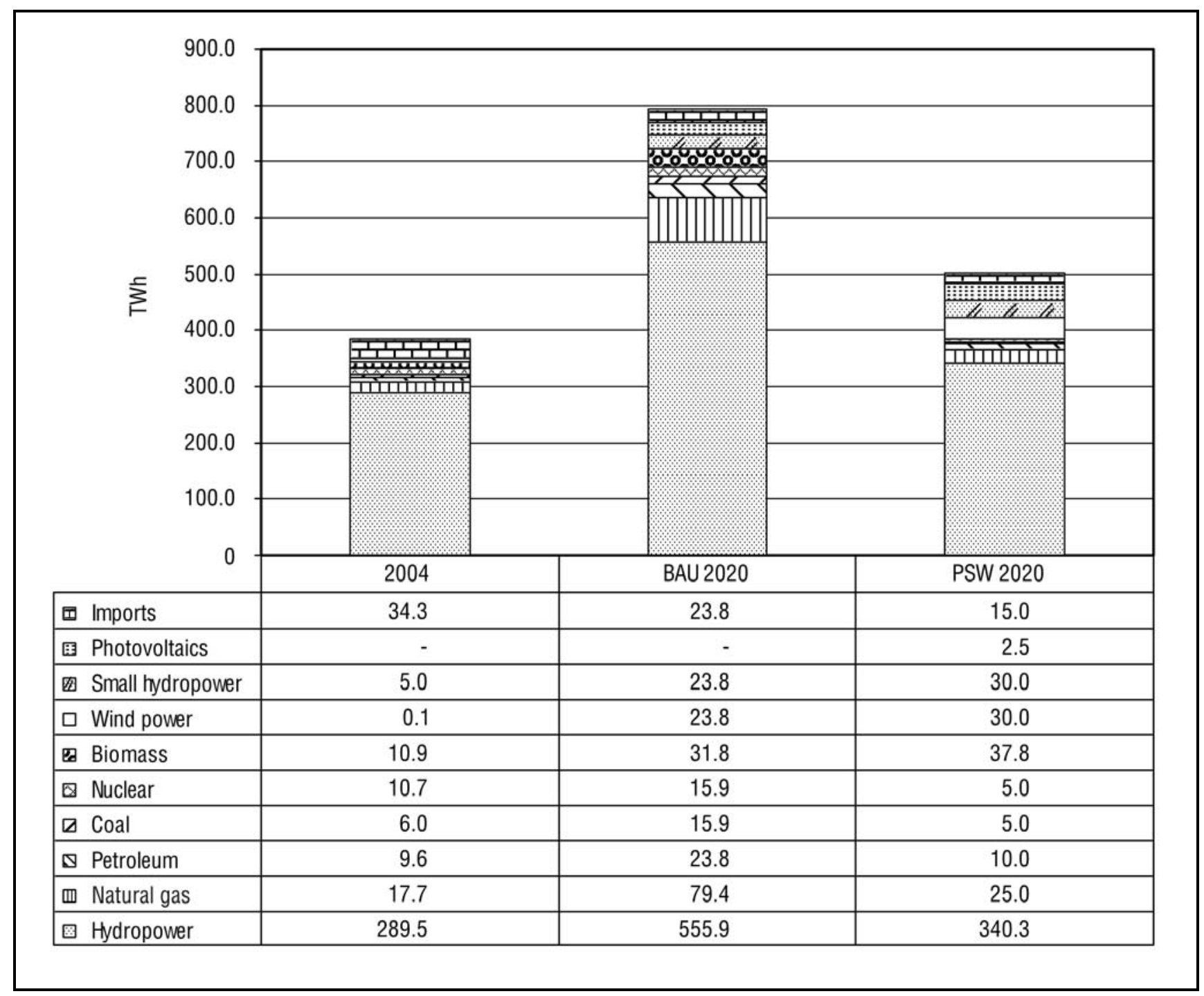

Figure 1. Electricity demand and fuel mix in 2004, and in 2020 under the BAU and PSW scenarios (TWh)

reduction in wind power costs by 2020 is estimated.

- Hydropower. With about $70 \mathrm{GW}$ installed in 2004, Brazil is the third largest hydropower producer, following Canada and China. An additional increase of about 5.5 GW was estimated. For small-scale hydropower growth rates of 2-3\% were assumed, resulting in an installed capacity of $6.9 \mathrm{GW}$ by 2020 , compared to an estimated potential of $2000 \mathrm{GW}$.

- Solar photovoltaics. High growth rates can be sustained for PV, but starting from a small base the technology will likely only make a significant impact by 2020 by supplying $1.6 \mathrm{GW}$. Given the prohibitively high cost of extending the grid to rural communities, solar energy can play an important role in promoting rural development.

- Coal. Coal-fired generation will represent $1 \%$ of power generation by 2020. Improved coal-burning technologies that are currently coming onto the market, such as supercritical boilers and integrated gasification combined-cycle systems, do not on their own reduce $\mathrm{CO}_{2}$ emissions sufficiently. Capturing the $\mathrm{CO}_{2}$ from fossil-fuelled power stations and storing it underground - geosequestration - is neither a mature technology nor commercially available at this point and as a result has not been included in this study.

- Nuclear power. No new nuclear power capacity is assumed, though the scenario contains existing nuclear capacity over the period to 2020, assuming a gradual phase-out, reaching $1.9 \mathrm{GW}$ in 2020 .

\subsection{Demand-side options}

Figures 3 and 4 provide an overview of the potential for electricity generation, including the following options.

- Efficient electric motor-driven systems. These use the largest amount of electricity in industry (about $60 \%$ of the total power consumed) and their energy performance can be increased through more efficient electric motors - which were assumed to be $20 \%$ more efficient by 2020 - and the use of variable-speed drives. This could result in a power saving of over 55,000 GWh by 2020 .

- Appliances, consumer electronics and office equipment. These devices account for a growing fraction of total electricity use in both households and workplaces. Energy-saving options include more efficient appliances, efficient cooling (refrigerators, freezers and air-conditioning equipment) and efficient lighting. 


\section{Articles}

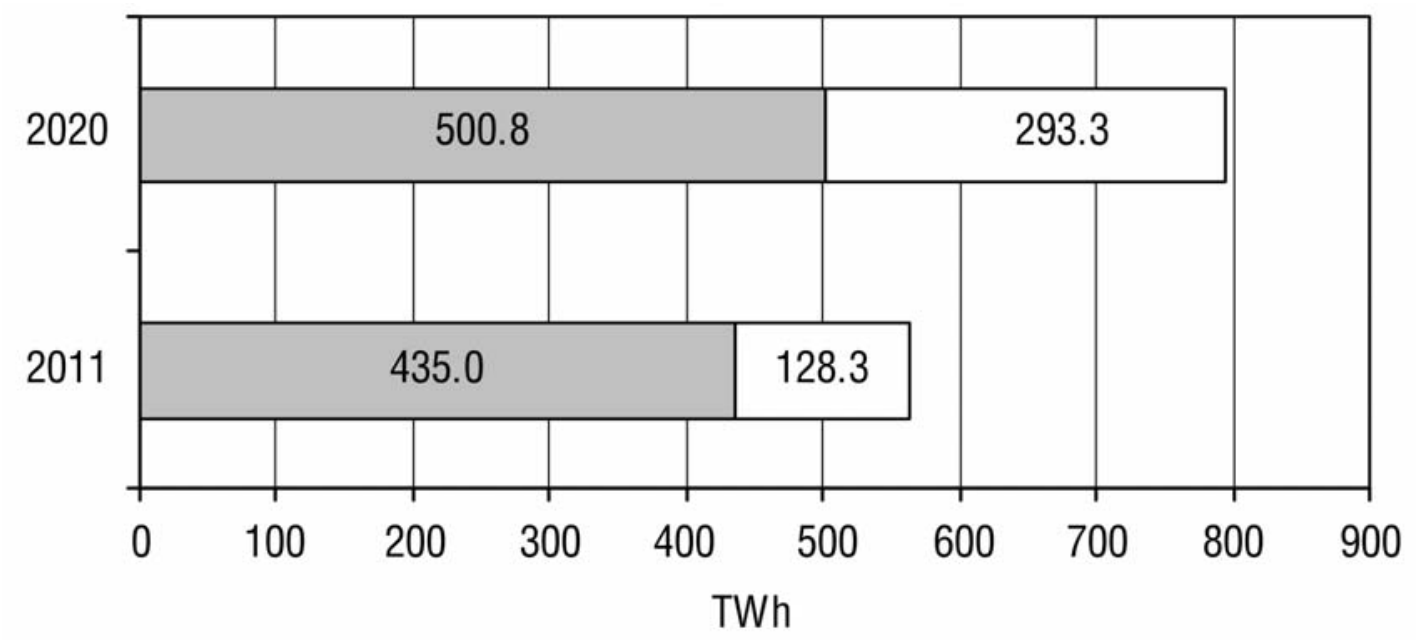

Energy saving potential

Figure 2. Total saving potential for electricity generation in 2011 and 2020 (TWh)

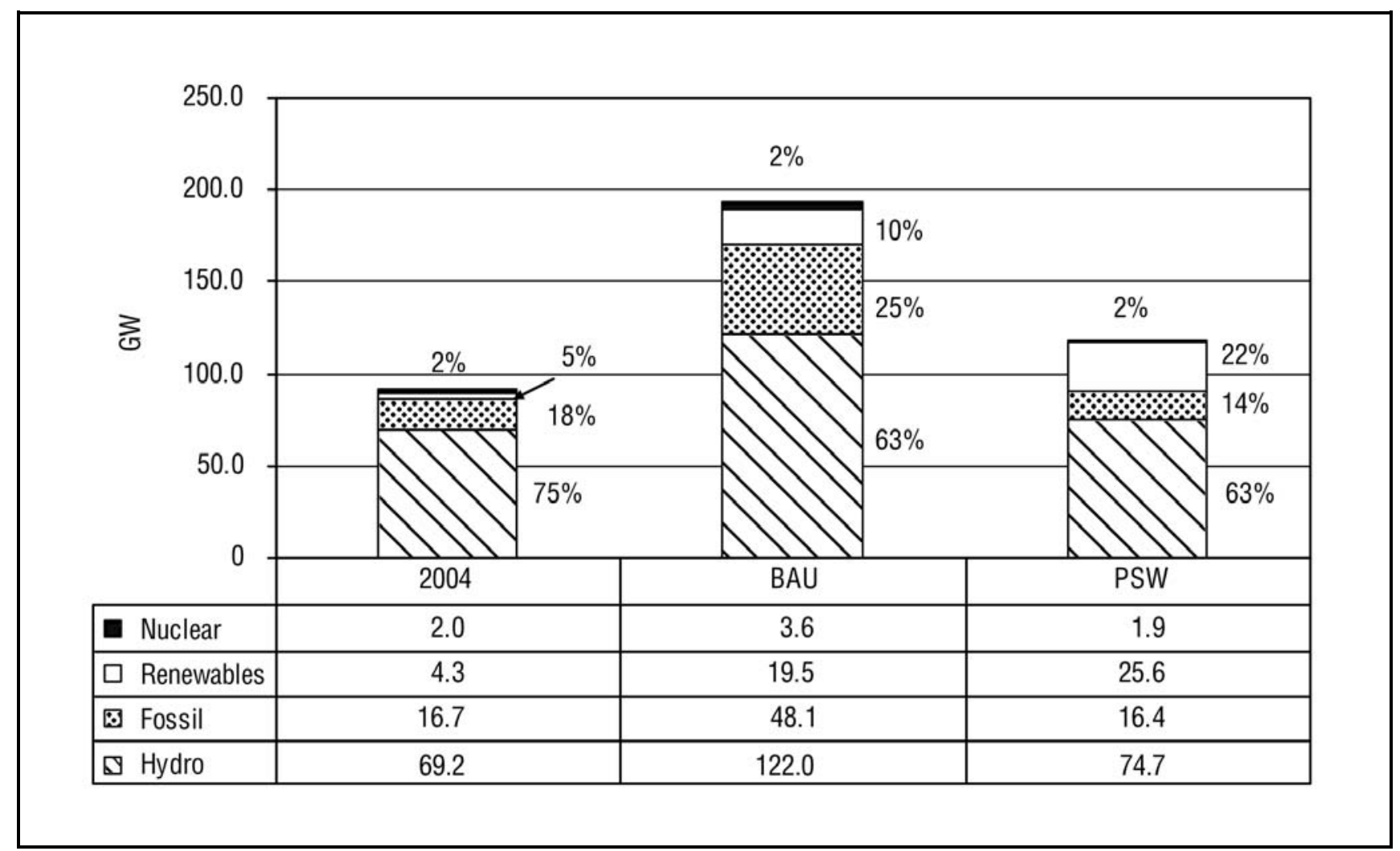

Figure 3. Installed capacity and fuel mix in 2004 and 2020 under the BAU and PSW scenarios (GW)

For instance, through the deployment of the best available technology, energy consumption of refrigerators - accounting for $30 \%$ of typical household consumption - could be cut by $40 \%$ on average, with a total power saving of $6,178 \mathrm{GWh}$ by 2020 . Stand-by and low-power-mode use by consumer electronics is responsible for about $10 \%$ of residential and service power demand in Brazil. Current regulation to reduce stand-by option energy use on appliances to $1 \mathrm{~W}$ is lacking implementation.
- Electric shower heaters. These systems consume $8 \%$ of all Brazil's electricity production and around $18 \%$ of the peak demand. Electrical shower-heads are in themselves extremely cheap, costing US\$ 10 or less. However, given their high life-cycle electrical consumption, each shower-head requires an investment of more than US\$ 1000 in new electricity generation capacity to guarantee the peak power needed to fuel them. They can be replaced by domestic solar water heater systems, especially when it comes to new 


\section{Articles}

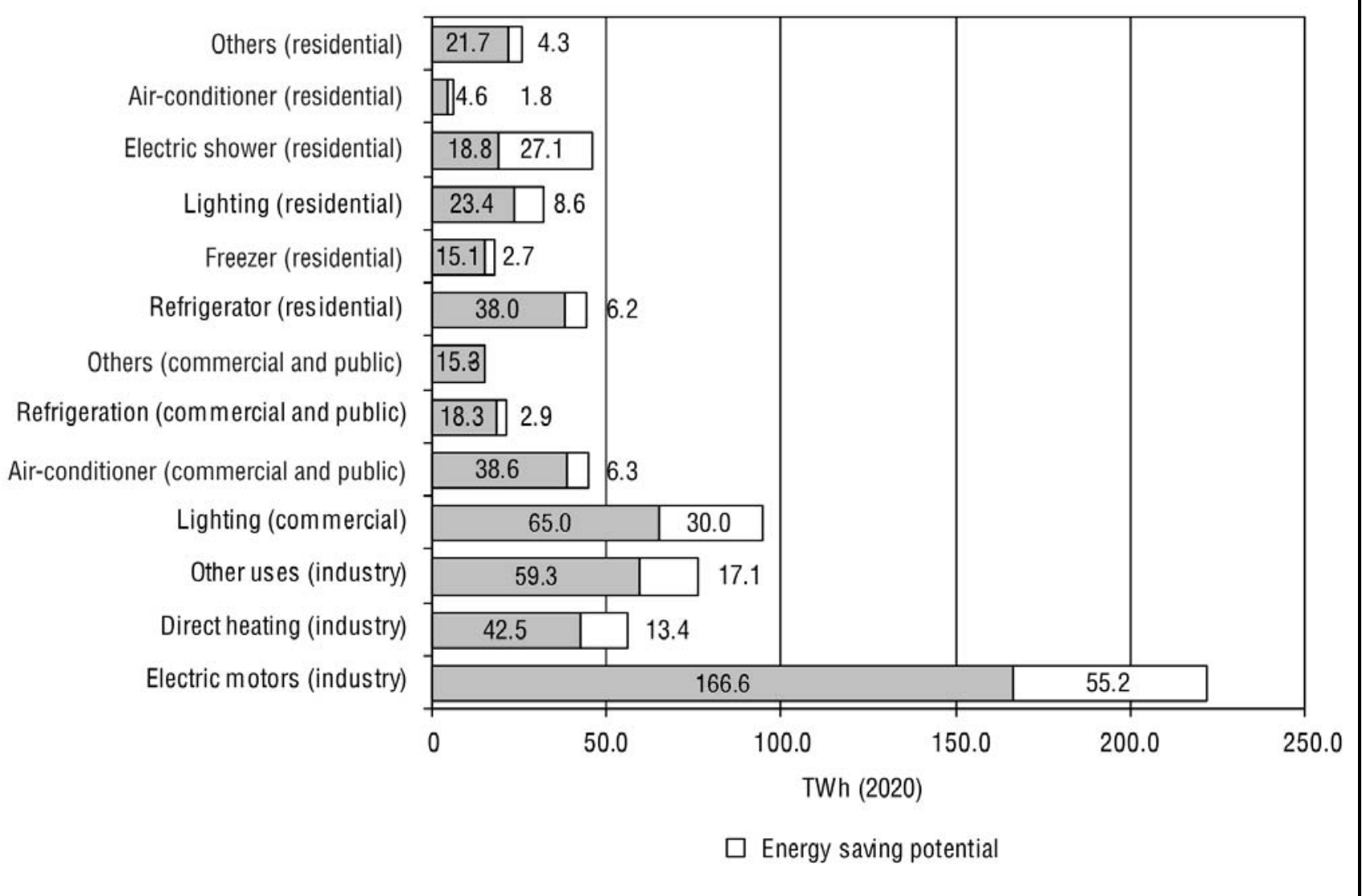

Figure 4. Energy efficiency potential for major end-uses by 2020 (TWh)

buildings or those with central heating systems that allow adaptations for solar thermal energy. The PSW scenario assumes a power-saving of over $27,000 \mathrm{GWh}$ by 2020 .

\section{The study's research findings}

\subsection{Business-as-usual scenario}

The main results for electricity demand under the BAU scenario are shown in Figure 1 and Figure 2. These estimates are based on a continuation of the current patterns of energy use in Brazil, where energy-intensive industries still consume about half of the total electricity production in 2020. Highlights include the following.

- Under the BAU scenario, power consumption is projected to increase by $4.8 \%$ annually, from $330.8 \mathrm{TWh}$ in 2004 up to $702.7 \mathrm{TWh}$ in 2020 , requiring a total installed generating capacity of $193.0 \mathrm{GW}$, up from the current 92.1 GW (Table 2).

- Generating capacity and output remains dominated by large-scale hydropower, though relatively decreasing, with an increasing share of fossil fuels, particularly natural gas (Figure 3). Also, $63 \%$ of the generating capacity will be based on hydropower in 2020, while fossil fuels and nuclear power will cover $27 \%$, followed by new renewables with $10 \%$.

- Natural gas-based electricity will grow from roughly 19.0 TWh in 2004 to just below 80.0 TWh by 2020 , equal to a $321 \%$ increase, which will make the country more dependent on unstable foreign supplies.

\subsection{The "Power Switch" scenario}

- Energy savings are the key difference with the BAU scenario. The PSW scenario projects total electricity demand at roughly $500 \mathrm{TWh}$ by 2020 , with savings totaling $290 \mathrm{TWh}$ (Figure 2 and Table 3) - equivalent to $75 \%$ of the electricity consumption in 2004 , bringing demand down by $38 \%$ by 2020 .

- The need for expensive investments in new power infrastructure could be avoided, providing a net economic and social benefit to the Brazilian people. Specifically, the need to construct $74.6 \mathrm{GW}$ of new electricity generation plant by 2020 could be avoided (Figure 3, Table 2) - equivalent to the capacity of 6 large hydropower plants of the Itaipu-type or $57 \mathrm{nu}-$ clear power facilities of the Angra III type.

- On the supply side, the share of renewable energy, including large hydropower, in the fuel mix increases up to $85 \%$ of the installed capacity by 2020 (Figure 3). New renewable energy options such as biomass (particularly sugar bagasse-fired cogeneration), wind power, and small hydropower deliver the major supply increase, totaling about $26.0 \mathrm{GW}$ of installed capacity.

- Under the PSW, there will be no need to build new fossil fuel power plants. Natural gas consumption will stabilize at 2004 levels, reducing the country's dependency on unstable foreign energy resources.

- Under the high levels of energy efficiency and main renewable energy measures assumed, $\mathrm{CO}_{2}$ emissions are stabilized at about 2004 levels (Figure 5). This is 


\section{Articles}

Table 3. Avoided generation and installed capacity in 2020 under the PSW scenario

\begin{tabular}{|c|c|c|}
\hline Measures & Avoided power generation (TWh) & Avoided installed capacity (GW) \\
\hline \multicolumn{3}{|l|}{ Supply-side options } \\
\hline Retrofitting hydropower plants & 39.8 & 10.131 \\
\hline More efficient new power plants & - & - \\
\hline Reduction of power losses & 49.2 & 12.511 \\
\hline Network management & 5.7 & 1.447 \\
\hline Cogeneration and distributed generation & 22.8 & 5.789 \\
\hline Subtotal & 117.5 & 29.878 \\
\hline \multicolumn{3}{|l|}{ Demand-side options } \\
\hline Efficient industrial motor technologies & 55.2 & 14.033 \\
\hline Direct heating + others & $30.5=13.4$ (heating) +17.1 & 7.766 \\
\hline Efficient domestic appliances & $\begin{array}{c}23.7=8.6 \text { (lighting) }+6.2 \\
\text { (refrigerator) }+2.7 \text { (freezer) }+1.8 \\
(\text { air-conditioning) }+4.3 \text { (others) }\end{array}$ & 6.023 \\
\hline Efficient commercial and public lighting and cooling + other & $\begin{array}{c}39.3=30.0 \text { (lighting) }+6.3 \\
(\text { cooling })+2.9 \text { (refrigerators })\end{array}$ & 9.983 \\
\hline Solar water heating & 27.1 & 6.894 \\
\hline Subtotal & 175.8 & 44.699 \\
\hline Total (supply + demand side options) & 293.3 & 74.577 \\
\hline
\end{tabular}

Note

Calculations on avoided installed capacity are based on an equivalent power plant with an average capacity factor of $45 \%$.

a $200 \%$ fall by 2020 compared to the BAU scenario. This will keep Brazil's leadership on low-carbon electric energy.

- Under the PSW scenario, inundated land will be reduced by a factor of seven compared to the BAU case, that is, $142 \mathrm{~km}^{2}$, down from $955 \mathrm{~km}^{2}$, leading to much lower socio-environmental impacts. Indeed, almost two-thirds of the country's hydro potential is in the rivers of the Amazon, meaning that under a BAU scenario the number of rain-forest, indigenous and riverbank communities affected by new dam infrastructure could rise significantly.

- The PSW scenario will create 10 million new and better jobs in the renewable energy sector - that is, 3.5 million more than the BAU scenario. In reality, employment creation is likely to be higher because the study does not account for the jobs created within the energy efficiency sector, for which there is a lack of data.

\section{Costs of market transformation}

The study has calculated the costs for implementing the BAU and PSW scenarios. The cost of the PSW scenario includes the costs of investment, transmission and distribution of the increased generated power, as well as the costs associated with implementing energy efficiency programs and deploying new renewable energy sources.

In comparing the cost-effectiveness of energy efficiency vs. supply-side options, the study aims at minimizing consumers' costs of meeting a specific end-use service. For this, it assumes higher discount rates for investments compared to those applied by the power sector. The cost of supplying electric energy is assumed to correspond to the end-use power tariff, so that it is possible to compare it with the cost of energy-saving measures. In 2004, the average electric tariff was R\$ $197.25 / \mathrm{MWh}$ and this is assumed to increase to R\$350/MWh by 2020 .

While a fully detailed economic assessment has not been carried out, some initial conclusions on the costs have been made. These show the following.

- The PSW scenario will be $12 \%$ less costly than the BAU scenario (see Figure 6). This is equivalent to US\$ 33 billion of savings by 2020 , resources that can be used to meet urgent socioeconomic development needs in the areas of health and education.

- As shown in Table 4, around half of the considered demand-side energy efficiency options can be implemented at a cost that is less than a third of the retail cost of electricity by 2020 and about half the current electricity tariffs.

- An important synergistic effect is that strong efforts to improve energy efficiency on the demand side will have a downward pressure on the electricity prices in Brazil.

\section{Conclusions}

The study shows that with an effective electricity demand reduction program and the aggressive adoption of policies stimulating renewable energy investment and efficient and retrofitted power facilities, Brazil will 


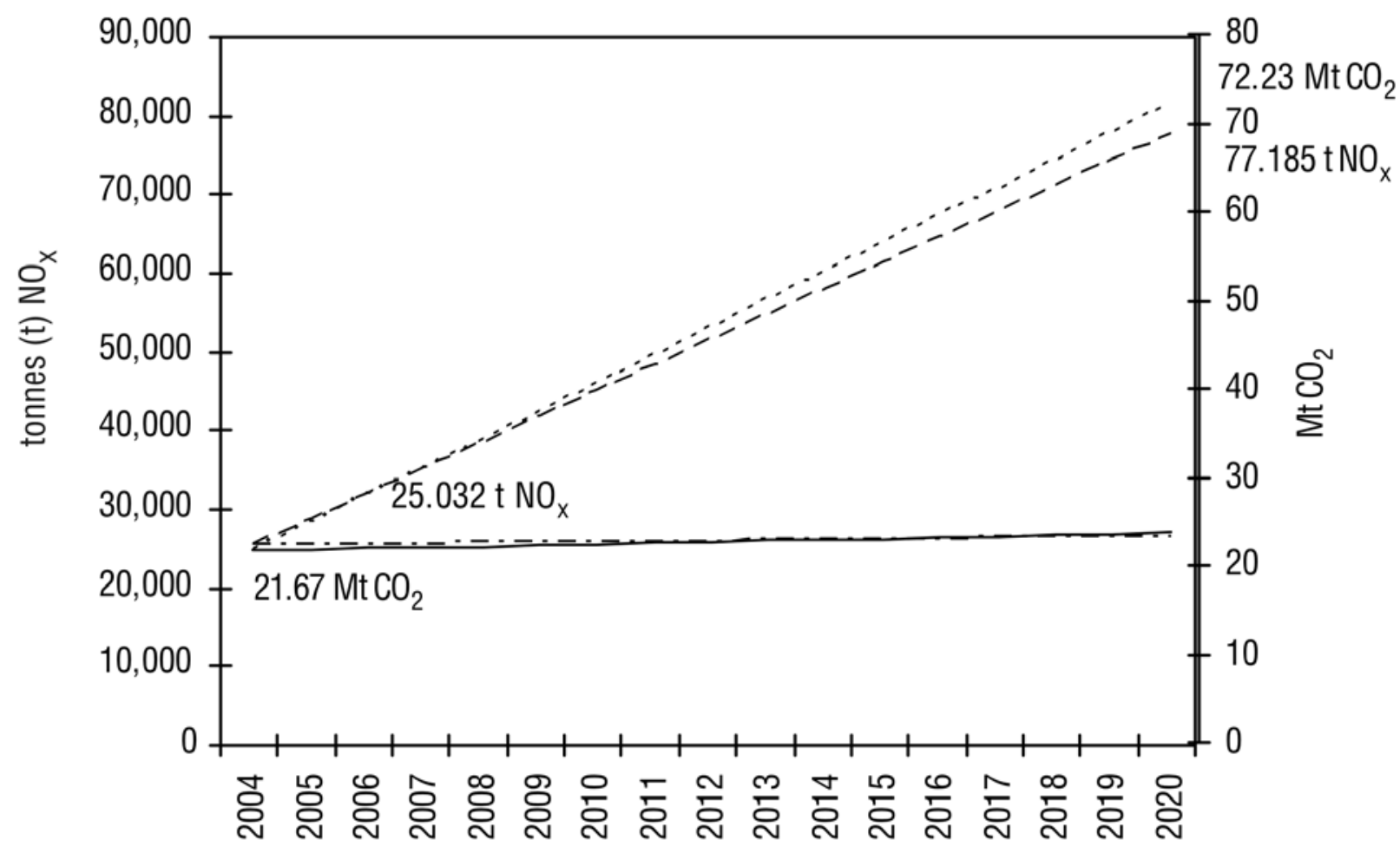

$----\mathrm{BAUNO}_{\mathrm{x}} \quad-\cdot \cdot-\mathrm{PSW} \mathrm{NO}_{\mathrm{x}} \quad \cdots \cdot \cdot \mathrm{BAUCO}_{2} \quad-\mathrm{PSW} \mathrm{CO}_{2}$

Figure 5. $\mathrm{CO}_{2}$ and $\mathrm{NO}_{\mathrm{x}}$ emissions from 2004 to 2020 under the $\mathrm{BAU}$ and PSW scenarios

meet its 2020 electricity needs at low cost and in a lowimpact way.

Only once supply-side and demand energy efficiency and conservation efforts have been fully implemented, and if proven to be less successful than projected, would additional generation measures such as more hydropower capacity need to be considered, assuming that the outstanding issues regarding its socio-environmental impacts and acceptance have been adequately addressed, through for instance, the full and effective implementation of the Commission on Dams Guidelines.

The major challenge for policy-makers will be in designing and stimulating an effective market and implementation programs for energy efficiency and renewable energy technologies. Brazil has the potential for being one of the first countries to have a low-carbon power sector beyond 2020 .

\section{Policy recommendations}

What then needs to be done for Brazil to realize its potential and make the transition to a more efficient, secure and sustainable power sector? As things now stand, Brazil's energy plans focus mainly on expanding power generation facilities, principally large dams and fossil-fuel power plants. In order to realise the PowerSwitch scenario by 2020 , the government must approve and deploy a stra-

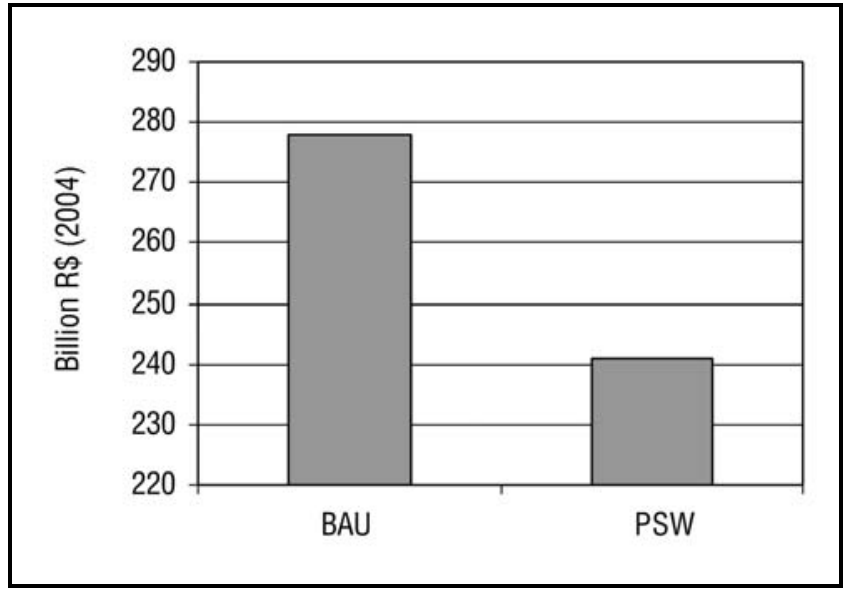

Figure 6. Total costs of the BAU and PSW scenarios (billion $\mathrm{R} \$$ )

tegic plan to foster effective implementation of energy efficiency measures, as well as expanded use of renewable energy sources. This plan should include the following nine measures.

1. Energy efficiency auctions. Energy efficiency should be fully integrated into the energy planning process, through energy efficiency auctions, where a specific amount of energy consumption is saved through energy conservation measures. This is an alternative way of enabling implementation of energy-saving measures 


\section{Articles}

Table 4. Saving potentials and costs of energy efficiency measures

\begin{tabular}{|l|c|c|c|}
\hline & $\begin{array}{c}\text { Cost } \\
\text { (R\$/MWh) }\end{array}$ & $\begin{array}{c}\text { Saving potential } \\
\text { (TWh) }\end{array}$ & $\begin{array}{c}\text { Total cost of energy efficiency } \\
\text { program and policy (million R\$) }\end{array}$ \\
\hline Electric heating head (residential) & 100 & 27.1 & 2,711 \\
\hline Lighting (commercial + public) & 100 & 30.0 & 2,998 \\
\hline Other uses (industrial) & 100 & 17.1 & 947 \\
\hline Lighting (residential) & 110 & 8.6 & 222 \\
\hline Air-conditioning (residential) & 120 & 1.8 & 761 \\
\hline Air-conditioning (commercial + public) & 120 & 6.3 & 1,613 \\
\hline Direct heating (industrial) & 120 & 13.4 & 803 \\
\hline Refrigerators (residential) & 130 & 6.2 & 353 \\
\hline Freezers (residential) & 130 & 2.7 & 381 \\
\hline Refrigeration (commercial + public) & 130 & 2.9 & \\
\hline Replacement of inefficient industrial motors (industrial) & 130 & 55.2 & \\
\hline Total & & & \\
\hline
\end{tabular}

Notes

Average national power tariff in 2004: R\$197.35/MWh [ANEEL, 2005]. Forecasted average supply cost by 2020: $\mathrm{R} \$ 350 / \mathrm{MWh}$. The costs were estimated from the substitution of conventional technologies by commercially available and more energy-efficient ones. Annual investment costs amortized over the equipment lifetime were considered at rates of return ranging from $15 \%$ to $80 \%$, depending on the end-use and consumer.

on the supply and demand sides through market agents. As far as end-use is concerned, this will make it possible to establish energy-efficient service companies (ESCOs) and, with regard to the supply side, it will boost the refurbishment of old large hydroelectric plants. These efficiency measures could deliver a potential of about 290 TWh by 2020 at a lower cost than would prevail in the relevant year.

2. Energy efficiency standards. Implementation of the energy efficiency law must become a priority by quickly approving more aggressive energy performance standards for appliances and motors ${ }^{[4]}$. To complement this, it is also necessary to foster more efficient technologies and processes throughout the supply chain. Hence, the government should approve high energy efficiency standards for industrial processes, focusing on energyintensive sectors and starting with the most inefficient segments with the largest potential for reductions. The implementation of such process standards must include financial and regulatory incentives, but also fines or penalties if the standard is not achieved in a given time. In addition, mandatory technical standards and use of research and development (R\&D) funds must be part of policies to reduce technical transmission and distribution costs.

3. Technological bids. The public sector accounts for approximately $10 \%$ of the total electricity consumption. Government agencies may set performance standards that will encourage manufacturers to develop and supply a given product to satisfy this demand. This sort of initiative is particularly important when associated to new technologies that have not yet been introduced on a significant scale into the market ${ }^{[5]}$.

4. Efficiency investment targets. Mandatory investments of electricity companies in their energy efficiency and R\&D programs, in addition to the Sectoral Energy Fund (CTEnerg) that is estimated at about R\$ 400 million/year, must be better managed so as to ensure maximization of their effectiveness ${ }^{[6]}$. Therefore, it is necessary to quantify the saving targets for such investment programs, improve capabilities for monitoring, checking and evaluating the outcomes in terms of saved MWh and avoided MW that are obtained from these resources.

5. National distributed generation program (PROGEDIS). The government should implement at national level a distributed generation program that includes stable and transparent incentives that make it possible to tap into the potential provided by these technologies, such as gas- and biomass-fired combined heat and power (CHP) and localised renewables ${ }^{[7]}$. Considering the large cogeneration potential from sugar cane bagasse use, valuation criteria and methods for auctions of new energy sources must be part of preliminary public hearing processes.

6. Incentive Program for Alternative Electric Energy Sources - Phase Two (PROINFA II). The government should announce a Phase Two of the PROINFA scheme, with the goal of increasing the share of renewable electricity to $10 \%$ by 2010 , and $20 \%$ by 2020. A more transparent program that involves less red tape and is adjusted to the needs of renewable energy producers would be a substantial gain during the second phase. 


\section{Articles}

7. National Solar Thermal Energy Program (PROSOLTER). In order to effectively tap into the huge potential of solar thermal energy in Brazil, a national program for this clean and cheap source of energy is required. This program must include development targets, financing incentives for consumers, and tax breaks, such as reduced taxes. Low-income populations may receive substantial benefits from such measures. It is fundamental to emphasize the need to mandate that proper devices be installed in new buildings. About $9 \%$ of total energy savings under the PSW scenario derive from implementation of a national program for the coverage of nearly a third of households across the country by 2020 .

8. Reduction of subsidies to conventional energy sources. Subsidies to fossil fuels spur wastage of electricity and make it difficult to introduce renewable sources of energy into the country's electricity generation mix. A reduction and eventual phase-out of such subsidies is necessary, such as the Fuel Consumption Account (CCC in Portuguese), which introduces biases into the market favoring fossil fuels such as coal and diesel. However, there must be differentiated treatment regarding use of CCC funds for the interconnected and the isolated electrical systems. For 2006, over R \$ 4.5 billion will be spent from the $\mathrm{CCC}$, i.e., 10 times more than the amount of mandatory investments to be made by electricity distribution companies under energy efficiency programs.

9. Awareness and education. The country has developed energy conservation awareness programs, be it through the National Electricity Conservation Program (PROCEL), the National Program to Rationalise the Use of Oil Products and Natural Gas (CONPET), or the energy companies themselves. Nevertheless, it is constantly necessary to follow up on the dissemination of up-to-date information on energy technologies and the most efficient ways of using the technologies and conserving energy. Significant barriers still exist, especially in terms of dissemination of technologies for thermal uses of solar energy in the household, industrial and office building sectors.

\section{Notes}

1. Gilberto Jannuzzi is also with International Energy Initiative - Latin American Regional Office, Caixa Postal 6163, Campinas - SP, CEP 13083-970, Brazil.

2. For more information, see [Swisher et al., 1997; Jannuzzi and Swisher, 1997; D'Sa 2005; Reddy et al., 1995a; 1995b].

3. Several authors have analyzed the existing barriers to energy efficiency and renewable energy and several proposals have been tried out to foster the development and diffusion of technologies and practices related to energy-efficient generation and use and renewables. Examples include [Reddy, 1991; Howarth and Anderson, 1993; USAID, 1997; Jannuzzi, 2000; Geller, 2003; Wiser et al., 2003; Goldemberg et al., 2003; Lewis and Wiser, 2005].

4. Mandatory standards are one of the instruments governments have utilized to eliminate inefficient equipment from the market and to stimulate the development of new energyefficient products [Birner and Martinot, 2005]. Some studies show dramatic energy consumption reductions for several appliances [Boardman et al., 1997]. There are important procedures and methodologies to be followed to guarantee rigorous analyses and cost evaluations, benefits to consumers, equipment manufacturers and society as a whole [Wiel and Mcmahon, 2001; Jannuzzi et al., 2002; Queiroz et al., 2003; Vendrusculo et al., 2003].

5. Developed countries have been using such mechanisms to stimulate the creation and expansion of technology-based companies and increase their competitiveness in the international market [Cate et al., 1998; Juma and Yee-Cheong, 2005].

6. Similar funds to support energy efficiency activities are an existing practice in several countries and there are several ways of governance, planning and evaluation of the funded activities [Cowart, 1997; Eto et al., 1998; Kozloff et al., 2000; Harrington and Murray, 2003; Wiser et al., 2003].

7. Some mechanisms have been important to the creation of a more competitive market for renewables, such as the Non-Fossil Fuel Obligation in the UK [Brower et al., 1996] and the Renewable Portfolio Standard in the US [Wiser et al., 1996; Langniss and Wiser, 2003; Wiser et al., 2003].

\section{References}

ANEEL (Agência Nacional de Energia Elétrica) (Brazilian Electricity Regulatory Agency). Tarifas médias de fornecimento por região, http://www.aneel.gov.br/98.htm, accessed on December 2, 2005.

BEN (Balanço Energético Nacional), 2005. Balanço Energético Nacional, Ministério das Minas e Energia.

Birner, S., and Martinot, E., 2005. "Promoting energy-efficient products: GEF experience and lessons for market transformation in developing countries", Energy Policy, Vol. 33, pp. 1765-79.

Boardman, B., Lane, K., Hinnells, M., Banks, N., Milne, G., Goodwin, A., and Fawcett, T., 1997. Transforming the UK Cold Market, Energy and Environment Program, University of Oxford, Oxford, UK, $112 \mathrm{pp}$.

Brower, M.C., Thomas, S.D., and Mitchell, C., 1996. The British Electric Utility Restructuring Experience: History and Lessons for the US National Council on Competition and the Electric Industry, http://eande.lbl.gov/ea/NationalCouncil/pubs/restdeba.html, accessed on November 20, 2001

Cate, A., Harris, J., Shugars, J., and Westling, H., 1998. "Technology procurement as a market transformation tool", ACEEE Summer Study on Energy-Efficient Buildings, Asilomar, CA.

Cowart, R.H., 1997. "Restructuring and the public good: creating a national system benefits trust", The Electricity Journal, Vol. 10, No. 3, pp. 52-57.

D'Sa, A., 2005. "Integrated resource planning (IRP) and power sector reform in developing countries", Energy Policy, 33(10), pp. 1271-1285.

Eto, J., Goldman, C., and Nadel, S., 1998. Ratepayer-funded Energy-Efficiency Programs in a Restructured Electricity Industry: Issues and Options for Regulators and Legislators, LBNL-41479, Lawrence Berkeley National Laboratory, Berkeley, May, 65 pp., http://eetd.lbl.gov/EA/EMP/

Geller, H., 2003. Revolução Energética: políticas para um futuro sustentável, Relume-Dumará/USAID, Rio de Janeiro, 299 pp.

Goldemberg, J., Coelho, S., and Lucon, O., 2003. "How adequate policies can push renewables", Energy Policy, Vol. 32, No. 9, p. 1141.

Greenpeace, 2006. Mudanças do Clima, Mudanças de Vida: Como o Aquecimento Global jà afeita o Brasil, Greenpeace, São Paulo.

Harrington, C., and Murray, C., 2003. Who Should Deliver Ratepayer Funded Energy Efficiency? A Survey and Discussion Paper, The Regulatory Assistance Project, Montpelier, VT, USA, $127 \mathrm{pp}$

Howarth, R., and Anderson, B., 1993. "Market barriers to energy efficiency", Energy Economics, October.

Jannuzzi, G.M., 2000. Políticas Públicas Para Eficiência Energética e Energia Renovável no Novo Contexto de Mercado, FAPESP/Editora Autores Associados, Campinas, 118 pp.

Jannuzzi, G.M., 2004. Uma Avaliação das Atividades Recentes de P\&D em Energia Renovável no Brasil e Reflexões para o Futuro, IV Congresso Brasileiro de Planejamento Energético, Sociedade Brasileira de Planejamento Energético, Itajubá.

Jannuzzi, G.M., 2005. Energy Efficiency and R\&D Activitities in Brazil: Experiences from the Wirecharge Mechanism (1998-2004), World Bank, Washington, 50 pp.

Jannuzzi, G.M., and Pagan, C.J.B., 2000. "The impacts of technical standards for incandescent lamp manufacture in Brazil", Energy, Vol. 25, pp. 1033-1045.

Jannuzzi, G.M., Queiroz, G.C., Borges, T., and Vendrusculo, E.A., 2002. Metodologia de análise de custo de ciclo de vida como suporte técnico à lei de eficiência energética: um estudo de caso para refrigeradores domésticos no Brasil, International Energy Initiative, Campinas, September, $28 \mathrm{pp}$.

Jannuzzi, G.M., and Swisher, J.N., 1997. Planejamento Integrado de Recursos: Meio Ambiente, Conservação de Energia e Fontes Renováveis, Editora Autores Associados, Campinas.

Juma, C., and Yee-Cheong, L., 2005. Innovation: Applying Knowledge to Development, UN Millennium Project, Task Force on Science, Technology, and Innovation, 220 pp.

Kozloff, K., Cowart, R., Jannuzzi, G.D.M., and Mielnik, O. 2000. Recomendações para uma Estratégia Regulatória Nacional de Combate ao Desperdício de Eletricidade no Brasil, 


\section{Articles}

USAID-Brasil, Campinas, $189 \mathrm{pp}$

Langniss, O., and Wiser, R., 2003. "The renewables portfolio standard in Texas: an early assesment", Energy Policy, Vol. 31, pp. 527-35.

Lewis, J., and Wiser, R., 2005. A Review of International Experience with Policies to Promote Wind Power Industry Development, Energy Foundation China Sustainable Energy Program, Center for Resource Solutions, $70 \mathrm{pp}$.

MME (Ministério de Minas e Energia), 2002. Plano Decenal de Expansão 2003/2012, Comitê Coordenador do Planejamento da Expansão dos Sistemas Elétricos, Brasília, DF.

MME (Ministério de Minas e Energia), 2006. Plano Decenal de Expansão 2006/2015, Secretaria de Planejamento e Desenvolvimento Energético, Brasília, DF.

NAE (Núcleo de Assuntos Estratégicos da Presidência da República), 2005. Mudança do Clima: Vulnerabilidade, impactos e adaptação à mudança do clima. Presidência da República, Secretaria de Comunicação de Governo e Gestão Estratégica, Brasilia.

Petrobrás, 2005. Plano Estratégico Petrobrás (2006-2010).

Queiroz, G.C., Jannuzzi, G.M., Vendrusculo, E.A., Borges, T., and Pomílio, J.A., 2003. A Life-cycle Cost Analysis (LCCA) for Setting Energy-efficiency Standards in Brazil: The Case of Residential Refrigerators, Energy Discussion Paper No. 2.56-01/03), International Energy Initiative, Campinas, May, 15 pp., http://www.iei-la.org.

Reddy, A.K.N., 1991. "Barriers to improvements in energy efficiency", Energy Policy, Vol. 19, pp. 953-61.

Reddy, A.K.N., D'Sa, A., Sumithra, G.D., and Balachandra, P., 1995a. "Integrated energy planning: Part 1. The DEFENDUS methodology", Energy for Sustainable Development, 2(3), pp. $15-26$.

Reddy, A.K.N., D'Sa, A., Sumithra, G.D., and Balachandra, P., 1995b. "Integrated energy planning: Part 2. Examples of DEFENDUS scenarios", Energy for Sustainable Development, 2(4), pp. 12-26.

Swisher, J., Jannuzzi, G.M., and Redingler, R., 1997. Tools and Methods for Integrated Resources Planning: Improving Energy Efficiency and Protecting the Environment, UNEP Collaborating Centre on Energy and Environment, Denmark, 270 pp.

USAID (United States Agency for International Development), 1997. Promoting Energy Efficiency in Reformed Electricity Markets: a Guidebook for Stakeholders, final report prepared for USAID/Office of Energy, Environment and Technology, Haigler Bailly Services, Inc., Washington, DC.

Vendrusculo, E.A., Queiroz, G.C., Jannuzzi, G.M., Mendes, N., Borges, T., and Pomílio, J.A. 2003. Technical Improvement of Residential Refrigerator in Brazil: Energy Efficiency Analysis, Energy Discussion Paper no. 2.56-2/03, International Energy Initiative, Campinas, May, 10 pp., http://www.iei-la.org.

Wiel, S., and Mcmahon, J., 2001. Energy-Efficiency Labels and Standards: A Guidebook for Appliances, Equipment, and Lighting, Collaborative Labeling and Appliance Standards Program (CLASP), Washington, DC, $205 \mathrm{pp}$

Wiser, R., Murray, C., Hamrin, J., and Weston, R., 2003. International Experience with Public Benefits Funds: A Focus on Renewable Energy and Energy Efficiency, Energy Foundation, China Sustainable Energy Program, $100 \mathrm{pp}$.

http://www.resource-solutions.org/Library/librarypdfs/IntPolicy-China.PBF.pdf

Wiser, R., Pickle, S., and Goldman, C., 1996. California Renewable Energy Policy and Implementation Issues - an Overview of Recent Regulatory and Legislative Action, LBL39247 UC-1321, Lawrence Berkeley National Laboratory, Berkeley.

World Bank, 2006. Financing Energy Efficiency Lessons from Recent Experience with a Focus on Brazil, China and India, ESMAP report, World Bank, Washington, DC.

\section{Subscribe now to Energy for Sustainable Development}

Annual subscription rates (for four issues)

\begin{tabular}{|l|c|c|c|}
\hline \multirow{2}{*}{ Individual (Web only) } & India & $\begin{array}{c}\text { Other developing } \\
\text { countries }\end{array}$ & $\begin{array}{c}\text { Industrialised } \\
\text { countries }\end{array}$ \\
\cline { 2 - 4 } & Rs. 450 & US\$ 10 & US\$ 50 \\
\hline Individual (Print, includes free web access) & Rs. 700 & US\$ 50 & US\$ 125 \\
\hline Institution (Print, includes free web access) & Rs. 2000 & US\$ 75 & US\$ 200 \\
\hline
\end{tabular}

\section{Payment options:}

By cheque, payable in India

Send a cheque in favour of "Energy for Sustainable Development" to:

Executive Editor, Energy for Sustainable Development, at the address given below.

With credit card, from outside India

Payments in US\$ may be made using the PayPal facility at //www.ieiglobal.org/PayPal.html

By wire transfer

Remittance should be made payable to:

Account No. CA-105, TIDE Account Energy for Sustainable Development

Canara Bank, Indian Institute of Science branch, Bangalore, India

Destination Swift Code: CNRBINBBLFD (Canara Bank, Foreign Division, Bangalore)

through any one of the following accounts:

04-427-255 with Bankers Trust Company, New York, Swift Code: BKTRUS33

0001-120066-001 with Canara Bank, London, Swift Code: CNRBGB2L

499080630-4711 with Dresdner Bank AG, Frankfurt, Swift Code: DRESDEFF

16-187211-1121 with Union Bank of California International, Tokyo, Swift Code: BOFCJPJT

When subscribing, please make sure to send an e-mail or fax containing details of subscriber's name, address and category of subscription to the ESD publication office.

Energy for Sustainable Development, c/o International Energy Initiative, 25/5 Borebank Road, Benson Town,

Bangalore 560 046, India

Tel/fax: (91-80) 2353 8426; E-mail: ieiblr@vsnl.com; http://www.ieiglobal.org/esd.html 